\title{
ОСОБЛИВОСТІ ПРОВЕДЕННЯ ПРАКТИЧНИХ ЗАНЯТЬ ПРИ ВИВЧЕННІ ІНТЕГРАЦЙНОГО КУРСУ «ДИТЯЧА ЛІТЕРАТУРА 3 МЕТОДИКОЮ НАВЧАННЯ ЛІТЕРАТУРНОГО ЧИТАННЯ»
}

\author{
Валерій Сиротенко \\ кандидат філологічних наук, доцент \\ ДВНЗ «Донбаський державний педагогічний університет» \\ м. Слов'янськ Донецької області, Україна \\ valerij.s.kram@gmail.com \\ Олена Бондаренко \\ старший викладач Краматорського інституту \\ ПРАТ «Міжрегіональна академія управління персоналом» \\ м. Краматорськ Донецької області, Україна
}

Анотація. У статті розглянуті особливості проведення практичних занять при вивченні вишівської дисципліни «Дитяча література з методикою навчання літературного читання». Вихідним положенням розвідки $є$ твердження, що інтегрування різних навчальних дисциплін - це об'єктивне веління часу, бо розвиває в майбутнього педагогічного фахівця здатність сприймати будь-яке явище в комплексі, розгалуженості, привчає знаходити вирішення проблем, що виникають, на підставі всебічного їхнього аналізу, урахування різних чинників, які потребують обов'язкового врахування.

Представлено варіанти двох практичних занять: твори комічного пафосу в дитячій літературі, їхнє вивчення в початковій школі (поезії Г. Бойка, вірш «Ділові розмови»); особливості аналізу творів ліричного роду літератури (вірш О. Олеся «В степу») та методичні підходи до вивчення пейзажної поезії в початкових класах (вірш Є. Горєвої «Ходить осінь в дібровоньці»). Сутність інтегрування полягає в тому, що набуті аналітико-літературні відомості повинні знайти доцільну методичну реалізацію на прикладі віршів шкільної програми з літературного читання.

Ключові слова: інтегроване навчання; практичне заняття; комічний пафос; гумор; сатира; іронія; гротеск; сарказм; лірика як рід літератури; пейзажний вірш; ліричний герой; алітерація; гіпербола; вступна бесіда; вибіркове читання; робота в парах; виразне читання.

Постановка проблеми в загальному вигляді. Однією з характерних ознак сучасного життя $є$ його прискорений темп. Це, зокрема, позначається й на представленні будь-якої інформації, її осмисленні та подальшому застосуванні. Наприклад, науковці установили, що 1986 року пересічна людина отримувала близько 40 умовних «газет» інформації щодня, а у 2007 році цей показник зріс до 174 [11]. Подібна проблема інформаційного переобтяження потребує відповідної реакції, одним зі шляхів розв'язання якої $є$ інтеграція. Адже саме інтеграція (від лат. integrum - ціле) дозволяє, опускаючи якісь незначні деталі, зосереджуватися на головному, формувати у вихованців бачення, сприйняття явища, що освоюється загалом, визначення його місця в загальній системі світорозуміння. Не випадково, аналізуючи зміст концепції «Нова українська 
школа», О. Бескорса відзначає, що перед сучасною українською школою ставиться завдання «сформувати в учнів цілісну картину світу й навички, які $\epsilon$ необхідними в реальному повсякденному житті <...>. Тому інтегроване навчання $є$ надзвичайно ефективним підходом, бо допомагає усвідомити учням важливу роль взаємодії одне з одним у реальному житті» [1, с. 230, 232].

Ми переконані, що успішна реалізація цього завдання можлива лише за умови, коли до класу зайдуть учителі нової формації, а саме це й реалізовується навчальним планом підготовки бакалаврів у галузі знань 0101 Педагогічна освіта за спеціальністю 013 Початкова освіта, яким передбачене вивчення дисципліни «Дитяча література 3 методикою навчання літературного читання». Однак тут одразу виникає певна проблема: розробники навчального плану зробили істотний крок уперед, але методичне оснащення цього навчального курсу ще не відповідає вимогам сьогодення. Тож в усуненні окресленої диспропорції й убачається актуальність нашої розробки.

Аналіз останніх досліджень i публікацій. На сьогодні проблема інтегрованого навчання здійснюється мінімум у двох аспектах: 1) осмислення сутності інтеграційних підходів до організації навчального процесу $[6 ; 10 ; 19]$; 2) особливості застосування інтегрованого навчання при вивченні конкретної дисципліни або підготовки спеціаліста певного фаху [7; 9; 15]. Але в обох випадках наголошується на тому, що врахування інтегративних можливостей у навчальному процесі - це веління часу, що відбиває об'єктивні тенденції розвитку сучасної цивілізації. При цьому наголошується на тому, що завдяки інтеграції передусім удосконалюються, посилюються інтелектуальні можливості того, хто навчається. Так, О. Титар та Г. Пінчук зауважують, що «інтегроване навчання, як ніяке інше, закладає нові умови діяльності викладачів та учнів, $\epsilon$ діючою моделлю активізації інтелектуальної діяльності та розвиваючих прийомів навчання» [19]. Стосовно переваг інтегрованого навчання цікаву думку висловлює Ж. Карташова, відштовхуючись від того, що на сьогодні надзвичайно зросло конкуренте протистояння, а вміння бачити, розуміти, оцінювати будь-яке явище в його взаємозалежності посприяє підвищенню фахової спроможності спеціаліста: «Процеси глобалізації, інформатизації та інтеграції суспільства ставлять вимоги до професійної компетентності, системності, розвинутості фахівця-універсала в умовах збільшеної конкуренції на ринку праці» [7, с. 193].

Останнім часом педагогами, методистами активно розглядається проблема впровадження змішаного навчання [5; 16]. Ми не будемо детально аналізувати сутність цієї педагогічної технології, але відзначимо, що й вона враховує особливості застосування інтеграції в процесі підготовки майбутнього вчителя: «Змішане навчання - це метод, який поєднує в собі традиційне навчання «обличчям до обличчя» і деякі елементи дистанційного навчання. Це поєднання традиційних формальних засобів навчання - роботи в аудиторіях, вивчення теоретичного матеріалу - із неформальними, наприклад, 3 обговоренням за допомогою електронної пошти та Інтернет-конференцій. Це цілеспрямований 
процес здобування знань, умінь і навичок в умовах інтеграції аудиторної та позааудиторної навчальної діяльності суб'єктів освітнього процесу на основі взаємного доповнення технологій традиційного, електронного, дистанційного та мобільного навчання» [5, с. 48$]$.

Як бачимо, інтегроване навчання знаходить належне науково-методичне обгрунтування, але не можна стверджувати, що дослідниками охоплені всі можливі аспекти вивчення позначеної проблеми, тому в подальшому ми й зупинимося на особливостях реалізації інтеграційних підходів на практичних заняттях при вивченні дисципліни «Дитяча література 3 методикою навчання літературного читання». Обираючи цю дисципліну, зауважимо, що в Інтернетмережах розміщено кілька робочих програм із дитячої літератури 3 планами практичних занять $[12 ; 13]$, але вони мають традиційний зміст і напрям практичних занять (вивчення творчості конкретного дитячого письменника аналіз його творів тощо), а це ще раз переконує в необхідності пошуку нових підходів до проведення практичних занять в умовах інтегрованого навчання.

Формулювання цілей статті (постановка завдання). 3 огляду на висловлені зауваження й міркування вважаємо за потрібне спинитися на таких моментах:

- уточнити деякі положення стосовно дидактико-методичних особливостей проведення практичних занять у ВЗО;

- виокремити низку творів із програми дитячої літератури різної проблематики, жанрів, художньої забарвленості, розгляд яких формуватиме в студентів навички літературознавчого аналізу, необхідні в подальшому вчителеві початкових класів при проведенні уроків літературного читання;

- підібрати зі шкільної програми низку творів подібної змістовохудожньої спрямованості, щоб зосередитися на методичних підходах щодо опрацювання цих текстів учнями початкової школи.

Результати дослідження. Практичні заняття давно набули чільного місця серед інших видів навчальної роботи у виші, даючи студентам можливість не лише розширити, поглибити теоретичні знання, а й набути необхідних практичних умінь і навичок. Однак, зважаючи на сучасні інтеграційні тенденції, уважаємо за потрібне внести певне уточнення щодо змісту дидактичних завдань практичного заняття, бо воно сприяє не лише засвоєнню «теоретичних положень навчальної дисципліни шляхом виконання спеціально сформульованих завдань та сприяє формуванню у них умінь і навичок практичного застосування цих теоретичних положень» [14], а й виробляє вміння сприймати будь-яке явище в його цілісності, органічній взаємодії з іншими об'єктами реальної дійсності, привчає вирішувати наявні проблеми комплексно тощо.

У розвідці ми наведемо приклади проведення двох практичних занять, кожне з яких має свою конкретну дидактично-методичну мету. Перше заняття присвячене проблемі комічного в дитячій літературі, зокрема з'ясуванню 
змістово-художніх особливостей поезій Грицька Бойка. Відповідно студентам пропонуються такі питання:

1. Сутність комічного як одного 3 пафосних наснажень художньої літератури. Місце комічного в дитячій літературі.

2. Прийоми творення комічного.

3. Змістово-художні особливості поезій Грицька Бойка («Знайду», «Хто кричав?», «Рибак та черв'як», «Змагання», «Як Хома збирався у похід»).

4. Методика роботи 3 вивчення вірша Г. Бойка «Ділові розмови» (2-й клас).

У зв’язку з тим, що ми вже висловлювали власні погляди щодо розуміння природи комічного в художній літературі, його змістових та формальних чинників [18], не будемо детально зупинятися на перших двох питаннях, лише відзначимо, що майбутні фахівці повинні вільно орієнтуватися в таких поняттях, як гумор, сатира, іронія, гротеск, сарказм, відрізняти змістові компоненти від формально-художніх засобів, бо програмою літературного читання для $2-4$ класів передбачена достатня кількість творів комедійного пафосу.

При розгляді поезій Грицька Бойка слід взяти до уваги певні особливості, властиві творчості гумориста загалом. Вони виявляються в тому, що героями $\epsilon$ переважно діти $10-12$ років із відповідним світосприйняттям і світобаченням. Хлопчакам, наприклад, важливо утвердити свій статус, заявити свої претензії на лідерство. Звідси намагання в усьому підкреслювати власну правоту, непогрішимість, відстоювати можливість прийняття особистих рішень. Однак ці наміри не завжди вписуються не лише в «дорослу» логіку, а й об'єктивний стан речей. Саме в цій невідповідності й коріниться природа Бойкового комічного, знаходячи вираження як в гумористичних, так і сатиричних ситуаціях, реалізованих переважно іронічно-гротесковими засобами. Так, на цілком резонне материне питання (вірш «Знайду»), для чого синові потрібні влітку калоші, той, не без хлоп'ячого подивування, спокійно запевняє неньку:

- Але ж грязюки там немає...

- Нічого, - я іiі знайду! [2].

Подібний принцип мислення властивий і героєві вірша «Хто кричав?» Сидячи в кріслі дантиста, Гриць, як кожна нормальна людина, не міг не почувати остраху, очікуючи на видалення зуба. Але ж гордість і честь хлопця не дозволяють зізнатися в цьому товаришам. Тож слабкодухим опиняється лікар, на якого Гриць і перекладає власний переляк (а хто перевірить!):

- Так то ж лікар заволав

Бо я став брикаться,

Йому щипці поламав

І ... вкусив за пальця! [3].

Бажання видаватися цілковитим господарем ситуації може набувати абсурдного вигляду, бо чим іншим виправдовується безглуздість заняття рибалки («Рибак та черв’як»), який не ловив рибу, а вчив «плавати черв’яка!» 
За цим безвинним невіглаством письменник підмічає й певні похибки в поведінці, які незабаром можуть обернутися і значно серйознішими моральними похибками. Школярі («Змагання») щиро змагаються за чистоту в класі, здіймаючи шалений гвалт, «бо ми за тишу вже змагались!» На перший погляд може здатися, що це дитяча безпосередність, але її основу становить підсвідомо запозичений від дорослих формалізм, на який здавна хворіє людство.

Однак Г. Бойко не забуває, що його основний читач - діти переважно молодшого й середнього шкільного віку, для яких піднято-збуджений, жартівливо-оптимістичний стан - ознака нормального психофізіологічного та інтелектуального розвитку дитини. Тому поет сам пропонує дітлахам посміятися, поглянути на себе через комічне дзеркало, яке не ранить серце, а насичує його радістю життя. Цьому власне сприяють такі вірші, як «Рятувальний пояс» та «Як Хома збирався у похід»: підготовка недосвідченого туриста до походу дійсно гротесково-гумористична, що ні в якому разі не ображає самого горе-мандрівника:

І сміються хлопчаки:

- Добрі в тебе рюкзаки!

Тільки треба для походу

Пару коней чи підводу! [4].

Отже, розкриттю цих особливостей і буде підпорядковано безпосередній аналіз віршів на практичному занятті. Його можна здійснювати приблизно за такою схемою:

1. Хто є героями віршів? Як автор ставиться до кожного з них?

2. У якому випадку звучить гумористичний, а в якому сатиричний сміх? Чому так оцінюється поведінка персонажів?

3. У яких поезіях переважає іронічне зображення, а в яких гротескове? Як досягається подібне зображення?

Уважаємо, що подібні завдання зосередять увагу студентів як на змістових, так і на формальних моментах комічного твору, привчать їх критично осмислювати зображені ситуації та персонажів, визначати художні особливості текстів, що буде потрібно в подальшій фаховій діяльності, бо змістовою лінією «Літературознавча пропедевтика» програми з літературного читання початкової школи передбачено, що діти повинні оволодіти найпростішими літературознавчими термінами, розкривати характер персонажа на підставі авторських характеристик, через дію, яскраві портретні деталі встановлювати авторське ставлення до персонажів, а також формулювати власне ставлення до зображуваного, знаходити характерні образні вирази для аргументації проголошеної думки.

Своєрідним закріпленням студентських навичок і вмінь аналізувати твори комічного характеру, які вироблялися впродовж практичного заняття, буде робота над опрацюванням можливих методичних підходів та прийомів, до яких варто вдатися вчителеві при вивченні вірша Г. Бойка «Ділові розмови» у 2-му 
класі. Видається, що на цьому етапі практичного заняття варто надати студентам максимальний ступінь самостійності, щоб вони змогли перевірити рівень власної готовності, дали йому самокритичну оцінку. Ця робота повинна закінчитися колективним обговоренням запропонованих методик, на підставі чого можна сформулювати приблизні методичні рекомендації.

Урок повинен розпочатися вступною бесідою вчителя, яка складатиметься 3 двох частин. У першій слід зупинитися на пафосних характеристиках художніх творів: героїчне, трагічне, комічне. Щоб другокласники сприйняли суто теоретичну інформацію на конкретно чуттєвому емоційному рівні, розповідь ведеться з опертям на три картини (рис. 1): ілюстрація до казки «Котигорошок» (героїчне), репродукція картини В. Васнецова «Оленка» (трагічне), кадр із мультфільму про Капітошку (комічне).

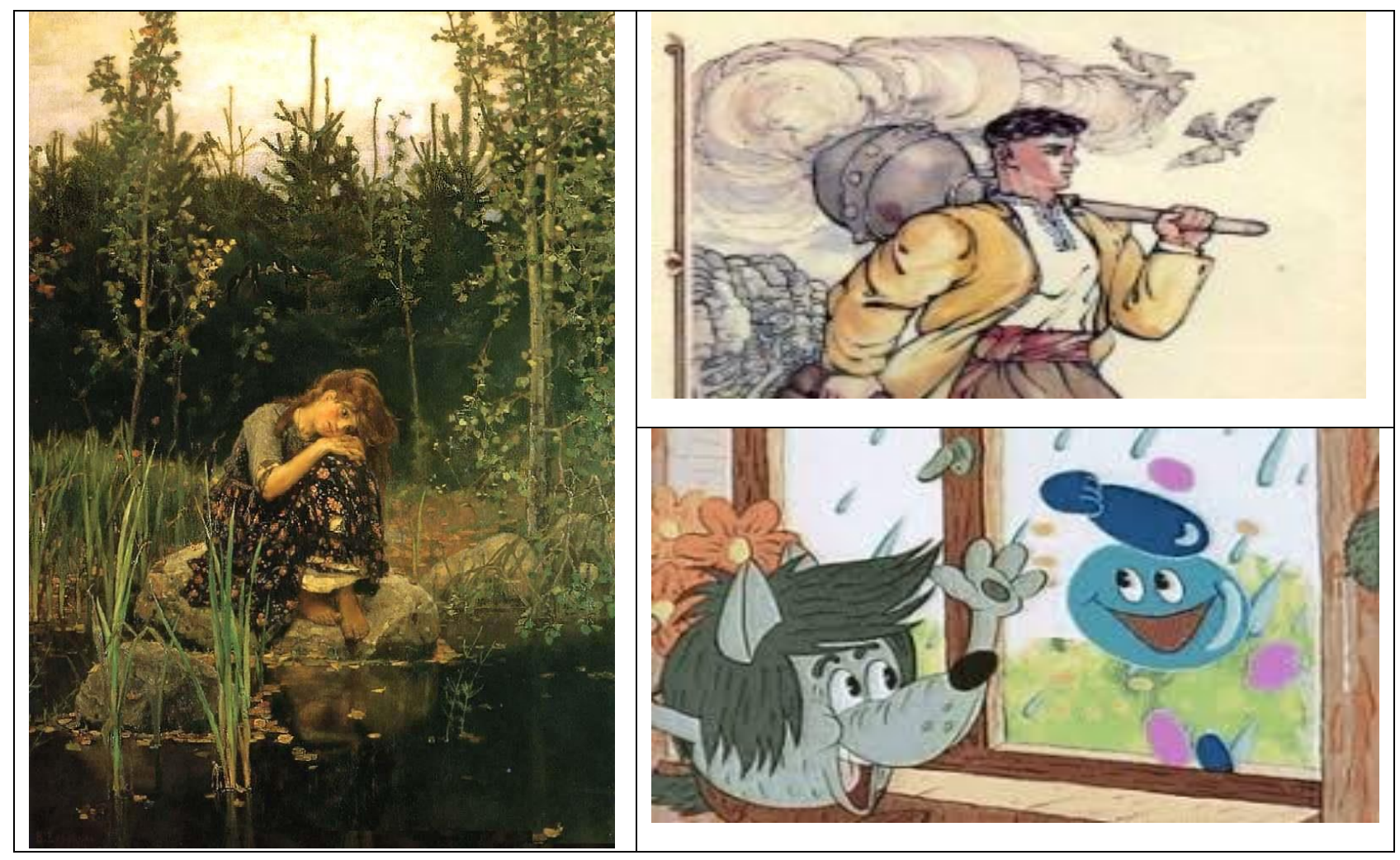

Рис.1. Приклади ілюстративного матеріалу

Демонстрація малюнків супроводжується приблизно такими питаннями: «Які почуття, переживання викликає у вас кожна з картин?», «Що ви відчуваєте до кожного з героїв, зображених на картині?», «Чи можете навести приклади 3 власного життя, які б відповідали настрою кожної з картин?». Подібна бесіда допоможе дітям усвідомити, що в мистецтві життя можна змальовувати порізному.

Друга частина вступної бесіди буде присвячена самому Г. Бойкові (основні відомості можна отримати на сайті https:/uk.wikipedia.org/wiki). При цьому 

«Дитяча література з методикою навчання літературного читання»

наголосимо, що, зважаючи на те, що студенти навчаються в Донбаському державному педагогічному університеті i більшість із них залишаються працювати на Донбасі, обов'язково слід підкреслити донецьке походження письменника, бо це важливо для утвердження в дітей відчуття батьківщини.

Після першого прочитання вірша відбувається розмова, мета якої не лише 3’ясувати, як учні зрозуміли зміст твору, а й акцентувати увагу на характерних художніх якостях, властивих саме тексту комічного наснаження. За основу вчитель може взяти завдання, подані в підручнику $[17$, с. 13], але доповнити їх власними, щоб посилити в школярів комедійне сприйняття поезії. Так, варто осмислити якість сміху, який лунає у творі. Для цього обговорюється не лише поведінка Петрика та Вови, а й те, як до цього ставиться автор, і як «зайнятість» хлопців оцінюється власне другокласниками. Це примусить школярів задуматися над тим, що сміх у вірші, який спочатку може видатися доволі добродушним (іронія), має більш осудливе, ніж жартівливе спрямування (таким чином формується розуміння гумористичного та сатиричного сміху та відчуття істотної різниці між ними).

У процесі подальшої роботи над віршем доцільно запропонувати учням знайти в тексті фрази, що повторюються («А що ти зараз робиш?»), а також прокоментувати репліку одного $з$ хлопчаків «... бо вже пора кінчати: // ще ж треба подзвонити // до Роми i до Гната» [17, с. 13]. Цим ще раз буде продемонстровано пустопорожність хлопчачого базікання, яке не може не викликати осудливого ставлення.

Завершується розгляд поезії роботою в парах, коли учні повинні інсценізувати діалог Петрика й Вови, прагнучи того, щоб голосовими інтонаціями не лише відтворити бажання хлопців вести «ділову розмову», а й передати власне ставлення до такої поведінки.

Як бачимо, ідея інтеграції на цьому практичному занятті полягає в тому, щоб допомогти студентам не лише засвоїти низку важливих літературознавчих понять, проаналізувати особливості сатирично-гумористичних поезій Г. Бойка, а й виробляти навички методично правильно, обгрунтовано організовувати роботу на уроці літературного читання, щоб діти отримали максимально повне уявлення про змістово-художні особливості твору, що вивчається.

Важливу роль у набутті теоретичних аналітико-літературних знань i методичних умінь і навичок належить ознайомленню з лірикою як родом та їі жанрово-тематичними групами (пейзажна лірика). Тому одне із практичних занять доречно присвятити розгляду дитячих поезій О. Олеся (збірка «Все навколо зеленіє»), зокрема розбору вірша «В степу», та методиці роботи 3 вивчення вірша Є. Горєвої «Ходить осінь в дібровоньці» (3-й клас).

Аналіз вірша О. Олеся дозволить закріпити такі поняття, як: символізм; образна система твору, його емоційне наснаження; алітерація; тропіка. Щоб студенти збагнули відзначені змістово-художні особливості поезіі, слід обговорити такі питання: 
1. У якому стані перебуває ліричний герой поезії, чим він обумовлений, які почуття в читача викликає цей твір?

2. Які образи можна виокремити у вірші, якими виражальними засобами вони творяться?

3. Які звукові асоціації викликає алітерація [дз - ц], як це звуконаслідування допомагає підкреслити душевні переживання ліричного героя?

4. Наскільки гіперболічний оксюморон «Світ в мені, і в світі я!» допомагає виразити ідею гармонічності світу між людиною та довкіллям?

Отже, поезія передає піднесено оптимістичний настрій ліричного героя, викликаний відчуттям повної гармонії між собою, природою, а найголовніше Всесвітом. Тому для ліричного героя весь навколишній світ - це величний храм, у якому душа не може не почувати возвеличення і вознесіння.

Отримавши таку «інтелектуальну розминку», студенти мають можливість виявити набуті знання, розробляючи методичні підходи щодо вивчення вірша «Ходить осінь в дібровоньці». Насамперед вони повинні врахувати, що твір належить до лірики як роду, а тому вступна бесіда спрямовується на творення в учнів відповідного душевно-емоційного стану. Його допоможе викликати прослуховування й перегляд сайту із записом «Осінньої пісні» 3 циклу П. Чайковського «Пори року» (http://mp3cc.com $/ \mathrm{m} / 4808102$ chajkovskij/28892765-pori-roku-os-nnya-p-snya-zhovten/). При цьому варто перед третьокласниками поставити завдання, щоб вони відзначили для себе найуразливіші звуково-зорові кадри, щоб потім зіставити їх із відповідними рядками поезії Є. Горєвої.

Після першого виразного прочитання вірша вчителем варто поцікавитися, що відчували вони, слухаючи поезію, які рядки з твору їм найбільше (і чому!) запам'яталися, чи переживали вони щось подібне, знаходячись в осінньому паркові або лісі.

При подальшій роботі над текстом доцільно здійснити вибіркове читання, коли школярі шукатимуть пестливу лексику (дібровонька, обновонька, доріженьки, ніженьки) та пояснюватимуть іiі роль у вірші. Також при вибірковому читанні треба зосередити увагу учнів на повторенні фрази «Кому треба...», щоб діти задумалися над тим, чим багата осінь, що від неї може очікувати й людина, і природа.

Вірш багатий на алітерації звукосполучень [cт, сх, ск], а тому це повинне стати предметом роздумів третьокласників: «Тихо чи голосно слід читати вірш?», «Як звучить музика П. Чайковського?», «Чому такий мелодійний малюнок обрали й композитор, і письменниця?».

Завершити аналіз поезії можна виконанням творчого завдання: підібрати до слова «осінь» слова, які б відповідали настрою твору, передавали особисте ставлення кожного з учнів до осінньої пори року. 
Особливості проведення практичних занять при вивченні інтеграційного курсу «Дитяча література з методикою навчання літературного читання»

Так, інтегроване заняття посилить усвідомлення студентами того, що лірика - це особливий рід літератури, звернений до суб'єктивного стану людини, а тому й потребує цілком відповідних шляхів як вишівського, так і шкільного аналізу, методичної вправності організувати роботу так, щоб реципієнт якомога глибше пройнявся авторськими емоціями, пережив їхню суголосність у власній душі.

Висновки з дослідження і перспективи подальших розвідок у цьому напрямі. У розвідці ми зупинилися лише на двох варіантах інтегрованого практичного заняття. Тож у подальшому можна зосередитися на таких питаннях:

- $\quad$ розроблення інших практичних занять інтегрованого курсу «Дитяча література з методикою навчання літературного читання»;

- $\quad$ особливості проведення інтегрованого заняття «лекція - практичне заняття» 3 цієї дисципліни;

- застосування інтегрованого навчання при викладанні методики навчання з різних предметів;

особливості методики проведення практичного заняття 3 літератури у виші та уроку літературного читання в початковій школі.

\section{СПИСОК ВИКОРИСТАНИХ ДЖЕРЕЛ}

1. Бескорса, О. (2017). Інтеграція на уроках англійської мови в початковій школі в контексті концепції нової української школи. Професіоналізм педагога: теоретичні $\check{u}$ методичні аспекти, 6, 230-238. Взято 3 http://pptma.dn.ua/files/2017/6/25\%20Beskorsa\%20230238.pdf

2. Бойко, Г. (б.д.). Знайду. Взято 3 http://www.megaznaika.com.ua/lyrics/znajdu/

3. Бойко, Г. (б.д.). Хто кричав? Взято 3 http://ua-referat.com/

4. Бойко, Г. (б.д.). Як Хома збирався $у$ nохід. Взято 3 http://portfel.info/dir/b/bojko_gricko/jak_khoma_zbiravsja_u_pokhid/337-1-0-1215

5. Бондаренко, Т. В. і Свтухова, Т. А. (2017). Деякі практичні аспекти підготовки майбутніх учителів початкової школи до використання змішаного навчання. Молодий вчений, 9.2 (49.2), 48-52.

6. Земляна, Е. (б.д). Інтеграиія знань в освіті. Технологія проведення інтегрованих занять. Взято 3 http://oldconf.neasmo.org.ua/node/2310

7. Карташова, Ж. (2016). Сучасні тенденції використання інтегративного підходу до організації інструментально-виконавської підготовки викладачів мистецьких дисциплін. Професіоналізм педагога: теоретичні ц̆ методичні аспекти, 3, 189-198. Взято 3 http://pptma.dn.ua/files/2016/3/21.Kartashova_s.189-198.pdf

8. Хорошковська, О.Н. і Охота, Г. І. (2013). Літературне читання 3 клас. Київ, Україна: Освіта.

9. Ліхвицька, Л. (2017). Інтегрований структурний комплекс мистецької інноваційної діяльності вчителів музичного мистецтва. Професіоналізм педагога: теоретичні й методичні аспекти, 6, 45-52. Взято 3 http://pptma.dn.ua/files/2017/6/5.\%20Likhitska\%2045-51.pdf

10. Любарська, О. М. (б.д.). Інтеграиійні прочеси в освіті. Взято 3 http://lib.chdu.edu.ua/pdf/zbirnuku/13/5.pdf

11. Ми споживаємо щодня у п'ять разів більше інформації, ніж 20 років тому, $\begin{array}{llllllll}\text { створюємо }- & \text { у } & 200 & \text { разів більше. (б.д.). Взято } 3\end{array}$ 
Особливості проведення практичних занять при вивченні інтеграційного курсу «Дитяча література $з$ методикою навчання літературного читання»

http://osvita.mediasapiens.ua/mediaprosvita/research/mi_spozhivaemo_schodnya_u_pyat_raziv_bil she informatsii_nizh_20_rokiv tomu_stvoryuemo_u_200_raziv_bilshe/

12. Мовчун, А. I. (2014). Робоча програма «Дитяча література». Взято 3 http://pi.kubg.edu.ua/images/stories/Departaments/idpmo/HaB4_Program/2014_DL_PO_2.pdf

13. Навчальний курс «Дитяча література». (б.д.). Взято 3 http://wiki.kspu.kr.ua/index.php

14. Практичні заняття. (б.д.). Взято з https://uk.wikipedia.org/wiki

15. Проворова, С. (2017). Міжпредметна інтеграція в методичній підготовці майбутнього вчителя музики на засадах праксеологічного підходу. Професіоналізм педагога: теоретичні й методичні аспекти, 5 (1), 235-247. Взято 3 http://pptma.dn.ua/files/2017/51/22.\%20Provorova\%20s.\%20235-246.pdf

16. Пучков, I. Р. (2017). Методологічні підходи до застосування змішаного навчання при підготовці майбутніх вчителів початкової школи. Молодий вчений, 9.2 (49.2), 76-80.

17. Савченко, О. Я. (2012). Літературне читання 2 клас. Київ, Україна: Видавничий дім «Освіта».

18. Сиротенко, В. П. (2011). Про сміх гумористичний, сатиричний і не тільки: деякі міркування з приводу категорій комічного. Вісник Донецького нащіонального університету. Гуманітарні науки, 2, 21-27.

19. Титар, О. В. і Пінчук, Г. Г. (б.д.). Інтеграція навчального процесу як чинник

$\begin{array}{lcc}\text { розвитку пізнавальної } & \text { активності } \\ \text { http://osvita.ua/school/lessons_summary/proftech/24899/ }\end{array}$

\title{
ОСОБЕННОСТИ ПРОВЕДЕНИЯ ПРАКТИЧЕСКИХ ЗАНЯТИЙ ПРИ ИЗУЧЕНИИ ИНТЕГРИРОВАННОГО КУРСА «ДЕТСКАЯ ЛИТЕРАТУРА С МЕТОДИКОЙ ОБУЧЕНИЯ ЛИТЕРАТУРНОМУ ЧТЕНИЮ»
}

\author{
Валерий Сиротенко \\ кандидат филологических наук, доцент \\ ГВУЗ «Донбасский государственный педагогический университет», \\ г. Славянск Донецкая область, Украина \\ valerij.s.kram@gmail.com \\ Елена Бондаренко \\ старший преподаватель Краматорского института \\ ЧАО «Межрегиональная академия управления персоналом» \\ г. Краматорск Донецкой области, Украина
}

Аннотация. В статье рассмотрены особенности проведения практических занятий при изучении вышевской дисциплины «Детская литература с методикой обучения литературному чтению». Изначальным положением исследования является утверждение, что интегрирование различных учебных дисциплин - это объективное требование времени, поскольку развивает у будущего педагога-специалиста способность воспринимать любое явление в комплексе, разветвленности, учит находить решения возникающих проблем на основании всестороннего их анализа, учета различных имеющихся показателей, требующих обязательной опоры на них.

Представлено варианты двух практических занятий: произведения комического пафоса в детской литературе, их изучение в начальной школе (поэзии Г. Бойко, стихотворение «Деловые разговоры»); особенности анализа произведений лирического рода литературы (стихотворение А. Олеся «В степи») и методические подходы относительно изучения пейзажной поэзии в начальных классах (стихотворение Е. Горевой «Ходит осень дубравушкой»). Сущность интегрирования состоит в том, что приобретенные аналитико- 
литературные сведения должны найти правомерную методическую реализацию на примере произведений школьной программы литературного чтения.

Ключевые слова: интегрированное обучение; практические занятия; комический пафос; юмор; сатира; ирония; гротеск; сарказм; лирика как род литературы; пейзажное стихотворение; лирический герой; аллитерация; гипербола; вступительная беседа; выборочное чтение; работа в парах; выразительное чтение.

\title{
FEATURES OF PRACTICAL CLASSES IN THE INTER-DISCIPLINARY COURSE “CHILDREN'S LITERATURE WITH THE METHODOLOGY OF TEACHING LITERARY READING" Valerii Syrotenko
}

\author{
Candidate of Philological Sciences, Associate Professor \\ SHEE "Donbas State Pedagogical University" \\ Sloviansk Donetsk region, Ukraine \\ valerij.s.kram@gmail.com \\ Olena Bondarenko \\ Senior Lecturer of Private College of Higher Education \\ "Kramatorsk Institute of Economics and Humanities" \\ Kramatorsk, Donetsk Region, Ukraine
}

\begin{abstract}
The article deals with the features of conducting practical classes in teaching the discipline "Children's Literature with the Methodology of Literary Reading" at university. The starting point of the study is the statement that the integration of various disciplines is an objective requirement of time, as it develops the future teacher's ability to perceive any phenomenon in the complex, branching, accustoms to find solutions to problems arising on the basis of their comprehensive analysis, taking into account various indicators that require the necessary reference to them. Integration allows, by omitting some insignificant details, to focus on the main points, to develop the students' vision and perception of the phenomenon being mastered, in general, to determine its place in the general system of world outlook. At the same time the attention is drawn to the fact that modern university syllabus provides the study of integrated disciplines ("Children's Literature with the Methodology of Literary Reading"), but there are practically no methodological tools of this training course. In this regard, we suggest two variants of an integrated practical lesson - a literary analysis of children's literature and methodological recommendations for works of similar content and artistic content that are part of the literary reading curriculum at primary school.

The first one is devoted to the problem of comic content in children's literature, in particular the clarification of the content and artistic features of the poetry of Hrytsko Boiko ("I'll Find", "Who Cried?", "The Fisherman and the Worm", "Competition"), as well as the definition of the peculiarities of methodological approaches to the study of poem H. Boiko "Business conversations" (the 2nd form). Analysing the works of comic pathos, it is necessary to take into account that it can be traced by different quality of laughter (humorous or satirical), realized by various methods of creating comic irony, grotesque, sarcasm, etc.

In order to understand the nature of the comic content in H. Boiko's poetry, one should take into account the age and gender of the heroes (mostly boys between 10 and 12 years old), so their intentions are "grown up", so it causes the emergence of comic situations that are often transmitted through grotesque situations ("I'll find", "How Khoma was going to the hike"), but they can have an ironic depiction ("Competition"). However, these characters call the author a condescendingly humorous attitude ("Fisherman and the worm"), and critically condemnable one ("Competition").
\end{abstract}

Професіоналізм педагога: теоретичні й методичні аспекти. - Вип. 7. - Слов’янськ, 2018. 


\section{Особливості проведення практичних занять при вивченні інтеграційного курсу «Дитяча література $з$ методикою навчання літературного читання»}

A peculiar fixing of students' skills and abilities to analyse the works of the comical nature (provided by the content line "Literary Propaedeutic"), which are made during the practical lesson, will be work on studying possible methodological approaches and techniques, which should be used by the teacher while studying the verse of $\mathrm{H}$. Boiko "Business conversations" in the 2 nd form. In this regard, we propose: an understanding of how the author relates to the behaviour of the boys (awareness of the fact that the work has a satirical orientation), selective reading with subsequent comments on isolated phrases (grotesque and ironic tone), work in pairs on explicit reading of dialogic replicas between Petryk and Vova (awareness of children not only the author's position in relation to characters, but their own one). It encourages the students to reflect on the fact that the laughter in the verse, which at first may seem rather good-natured (irony), has a more condemnable character than a humorous way (thus the understanding of humorous and satirical laughter and a sense of significant difference between them is developed).

The analysis of works belonging to lyric poetry as generic literature, in particular landscape lyrics, requires the following literary and methodological approaches: creating the associative bushes (listening to P. Tchaikovskyi's "Autumn Song”), searching and vocabulary work (revealing in the text of the petty vocabulary and explaining its content and expressive role), commenting alliterative sound combinations, performing a creative task (the selection of own definitions for the word "autumn").

Key words: integrated learning; practical lesson; comic pathos; humour; satire; irony; grotesque; sarcasm; lyricism as a genus of literature; landscape poem; lyrical hero; alliteration; hyperbole; introductory conversation; selective reading; work in pairs; expressive reading.

\section{REFERENCES}

1. Beskorsa, O. (2017). Integration at english lessons in primary school in the context of the new ukrainian school concept. Profesionalizm pedahoha: teoretychni y metodychni aspekty, 6, 230-238. Retrieved from http://pptma.dn.ua/files/2017/6/25\%20Beskorsa\%20230-238.pdf

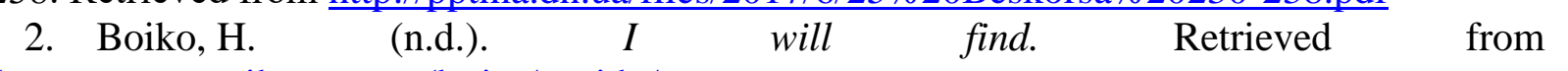
http://www.megaznaika.com.ua/lyrics/znajdu/

3. Boiko, H. (n.d.). Who screamed? Retrieved from http://ua-referat.com/

4. Boiko, H. (n.d.). How was Khoma going to the hike. Retrieved from http://portfel.info/dir/b/bojko_gricko/jak_khoma_zbiravsja_u_pokhid/337-1-0-1215

5. Bondarenko, T. V. \& Yevtukhova, T. A. (2017). Some practical aspects of the preparation of future primary school teachers to use mixed learning. Molodyi vchenyi, 9.2 (49.2), $48-52$.

6. Zemliana, E. (n.d.). Integration of knowledge in education. Technology of carrying out of integrated classes. Retrieved from http://oldconf.neasmo.org.ua/node/2310

7. Kartashova, Zh. (2016). Modern tendencies of using integrative approach to organizing art teachers' instrumental and performing training. Profesionalizm pedahoha: teoretychni $y$ metodychni aspekty, 3, 189-198. Retrieved from http://pptma.dn.ua/files/2016/3/21.Kartashova_s.189-198.pdf

8. Khoroshkovska, O. N., \& Okhota, H. I. (2013). 3rd Grade Literary Reading. Kyiv, Ukraine: Osvita.

9. Likhvytska, L. (2017). Integrated structural complex of art innovative activities of musical art teachers. Profesionalizm pedahoha: teoretychni y metodychni aspekty, 6, 45-52. Retrieved from http://pptma.dn.ua/files/2017/6/5.\%20Likhitska\%2045-51.pdf

10. Liubarska, O. M. (n.d.). Integration Processes in Education. Retrieved from http://lib.chdu.edu.ua/pdf/zbirnuku/13/5.pdf

11. We consume five times more information every day than 20 years ago, we create -200 times more. (n.d.). from 


\section{ВАЛЕРІЙ СИРОТЕНКО, ОЛЕНА БОНДАРЕНКО}

Особливості проведення практичних занять при вивченні інтеграційного курсу «Дитяча література 3 методикою навчання літературного читання»

http://osvita.mediasapiens.ua/mediaprosvita/research/mi_spozhivaemo_schodnya_u_pyat_raziv_bil she informatsii_nizh_20_rokiv_tomu_stvoryuemo_u_200_raziv_bilshe/

12. Movchun, A. I. (2014). Work Program "Children's Literature". Retrieved from http://pi.kubg.edu.ua/images/stories/Departaments/idpmo/HaB4_Program/2014_DL_PO_2.pdf

13. Training course "Children's Literature". (n.d.). Retrieved from http://wiki.kspu.kr.ua/index.php

14. Practical lessons. (n.d.). Retrieved from https://uk.wikipedia.org/wiki

15. Provorova, Ye. (2017). Interdisciplinary integration in future music teachers' methodological training on the basis of praxeological approach. Profesionalizm pedahoha: teoretychni y metodychni aspekty, 5 (1), 235-247. Retrieved from http://pptma.dn.ua/files/2017/51/22.\%20Provorova\%20s.\%20235-246.pdf

16. Puchkov, I. R. (2017). Methodological approaches to the use of mixed learning in the preparation of future teachers of primary school. Molodyi vchenyi, 9.2 (49.2), 76-80.

17. Savchenko, O. Ya. (2012). 2nd Grade Literary Reading. Kyiv, Ukraine: Vydavnychyi dim "Osvita".

18. Syrotenko, V.P. (2011). About laugh humorous, satirical, and not only: some considerations about categories of comic. Visnyk Donetskoho natsionalnoho universytetu. Humanitarni nauky, 2, 21-27.

19. Tytar, O. V. \& Pinchuk, H. H. (n.d.). Integration of the educational process as a factor in the development of cognitive activity of students. Retrieved from http://osvita.ua/school/lessons_summary/proftech/24899/

Матеріали надійшли до редакції 03.04.2018 p. 